\title{
The brazilian logistics service provider on the internet
}

\section{O prestador de serviços logísticos brasileiro na internet}

\author{
Mauro Vivaldini ${ }^{1}$ (1), Silvio Roberto Ignácio Pires² [1] \\ ${ }^{1}$ Universidade Paulista - UNIP, Itupeva, SP, Brasil. E-mail: mavivald@gmail.com \\ ${ }^{2}$ Fundação Getúlio Vargas - FGV Management, Rio de Janeiro, RJ, Brasil. E-mail: sripires@fgvmail.br
}

How to cite: Vivaldini, M., \& Pires, S. R. I. (2020). The brazilian logistics service provider on the internet. Gestão \& Produção, 27(4), e4430. https://doi.org/10.1590/0104-530X4430

\begin{abstract}
The attention of Logistics Service Providers (LSPs) to market movements and trends is fundamental to winning accounts, as well as avoiding problems and keeping customer companies. In this context, the primary purpose of this article was to identify, characterize and analyse the types of logistics outsourcing in Brazil, to evaluate the LSPs concerning the capacity of integration in the supply chains (SC), through the positioning and offer of services that they adopt on their websites. Therefore, the theoretical discussion pointed out the importance of websites for organizations, considering the company's website as an essential communication channel. The study researched 154 websites of these providers in Brazil aiming to understand if the attributes and competencies disclosed are aligned with the theory. The results show that the majority (59\%) of LSPs in Brazil are unable to articulate and present their skills in the same way that they are discussed in theory.
\end{abstract}

Keywords: LSP; Internet; Logistics; Supply chain; 3PL; 4PL.

Resumo: A atenção dos Prestadores de Serviços Logísticos (PSL) aos movimentos e tendências do mercado é fundamental para conquistar contas, como também evitar problemas e manter as empresas clientes. Neste contexto, este artigo tem como propósito principal identificar, caracterizar e analisar os tipos de terceirização logística existentes no Brasil, avaliando os PSL em relação à capacidade de integração nas cadeias de suprimentos (CS), por meio do posicionamento e oferta de serviços que adotam em seus sites. A discussão teórica aponta a importância dos websites para organizações, considerando o site da empresa como seu principal canal de comunicação. Pesquisou-se 154 sites destes provedores no Brasil, segundo os atributos e as competências evidenciadas na teoria e que caracterizam um PSL. A pesquisa realizada deixou claro que a maioria $(59 \%)$ dos PSL no Brasil não consegue articular e apresentar suas competências de forma clara a quem consulta seus sites.

Palavras-chave: PSL; Internet; Logística; Cadeia de suprimentos; 3PL; 4PL.

\section{Introduction}

The logistics services market is characterized by relatively low-profit margins, around $4 \%$ to $5 \%$ (Lieb, 2008; Min et al., 2013). Thus, the survival and expansion of Logistics Service Providers (LSPs) are directly related to the management of these

Received June 20, 2018 - Accepted Apr. 17, 2019

Financial support: None.

This is an Open Access article distributed under the terms of the Creative Commons Attribution License, which permits unrestricted use, distribution, and reproduction in any medium, provided the original work is properly cited. 
margins and to the ability to operating integrated services through contracts with a longer term and better predictability (Vivaldini \& Pires, 2010).

Despite this, according to research conducted with 100 professionals in the area in Brazil, $85 \%$ of LSP contractors mentioned that they are satisfied or delighted with the services they perform (ILOS, 2014). If on the one hand, this seems to be very positive, on the other hand, it can cause those involved to be so satisfied with what they have achieved they make no further effort, not encouraging improvements or innovations that add results capable of benefiting both the LSP and contractor. However, data from the same survey show that $78 \%$ of companies tend to replace their LSPs, which shows little loyalty or a low level of aggregation of specific services, reinforcing the thinking that hiring occurs more in primary services such as warehousing and transportation. Besides, such research shows that for the investigated companies, two-thirds of logistics expenditures were directed to the payment of LSPs, and $40 \%$ planned to increase the level of outsourcing of logistics processes. Thus, to increase the market share, LSPs must understand the needs of the market and know what the contracting companies are looking for. Thus, they can determine where to invest their capital and undertake their efforts (ILOS, 2014).

LSPs can qualify for strategic alliances and move towards a more collaborative relationship with its customers. This strategy differs from commoditized basic services and leads to the development of new activities, mainly in the use of Information and Communication Technology (ICT). Moreover, by operating with several and different customers, they can assimilate solutions capable of helping and facilitating operations (Sharma \& Choudhury, 2014). Moreover, authors such as Vivaldini \& Pires (2013) defend the idea that the main reason for strengthening alliances and the relationship with the LSP are the innovations linked to projects that require an inter-organizational relationship, thus leaving the basic transactions.

In a more strategic view of these providers in Brazil, Ferreira et al. (2016) argue that they have different behavior with the value proposition of their businesses, stating that large operators concentrate on offering a complete package of services. Medium-sized companies concentrate on offering convenience solutions, that is, packages that rely on some services performed by their partners or those with whom they maintain strategic alliances. Small logistics companies often end up personalizing their services. Along these same lines, however, concerning the type of transaction, Vivaldini \& Pires (2013) state that the contracting company can see the LSP services as:

- Simple transaction: represented by contracting a service, something specific;

- Repeated transactions: when the service is used frequently but is not formalized as such;

- Outsourcing agreement: there is a formalization (contractual), in which the service is transferred to be executed by an LSP. However, the supervision is the responsibility of the customer company;

- Partnership agreement: when contracting an LSP with predefined responsibility and performance indicators (KPI) to be fulfilled by the LSP;

- Integrated Services Agreement: when the LSP is seen as part of the customer's business, and the relationship is marked by commitment.

Singh Bhatti et al. (2010) consider that logistical outsourcing occurred in specific areas for specific providers, and then more broadly for the so-called LSP. However, the increasing number of these providers in the market ended up leading to a vast range of services offered by them. For these authors, something went wrong along these 
lines. Some LSPs have failed in their business transformation. For example, LSPs with expertise in international business have failed to provide domestic services and viceversa. Consequently, the commodification of LSP services contributed to dismantling its original basic purpose, which is to provide more customized services to customer companies.

LSPs need to be attentive to market movements and trends. According to Liu et al. (2015), logistics services have often been seen as problematic by customer companies, which explains the growing insourcing movement when the service performed by a third party returns to the contractor (Vivaldini, 2015).

In this context, the primary purpose of this article is to identify, characterize and analyse the types of logistics outsourcing in Brazil, to evaluate the LSP concerning the capacity of integration in the supply chains (SC), through positioning and offering services that they adopt on their websites. Thus, the research highlights the importance of websites, supported by Rosenthal (2017) regarding the importance of the company being up to date with technologies, and through them increasing interaction with customers, motivating them to know their services better.

\section{LSPs (Logistics Service Providers)}

Companies have outsourced not only the traditional distribution activities to LSPs, such as warehousing and transportation operations, but also management activities related to the flow of goods and productive activities. At the same time, LSPs have developed their capabilities by expanding the offer of services with solutions adapted to specific customers or segments. Therefore, an increasing number of companies have part of their supply chain located externally and outside their direct control, that is, not executed by them (Fabbe-Costes et al., 2009). Hence, over the last decades logistical services have expanded beyond the provision of isolated services (such as transportation and storage) for the management and handling of the flow of goods throughout the supply chain (Kersten \& Koch, 2010). The logistics services market has grown and has been increasingly segmented, both by the industrial sector and by the type of operations being carried out. It has also added more and more management activities and not only the execution of logistical operations. Thus, current providers of necessary logistics services are often considered as providers of second-party logistics services, called 2PLs (two-party logistics). Freight and storage service providers, among others, fall into this category. In many cases, they act as subcontractors for outsourced logistics providers, called 3PLs (third-party logistics), who provide complete packages of integrated logistics services. With a broader scope and directed to the activities related to supply chain management, another class appears directed to logistics services outsourcing, called 4PLs (fourth-party logistics). Its performance is characterized by managing materials and information flows throughout the supply chain of several customer companies, acting as an integrating agent and seeking to generate synergies that benefit all its customers.

Considering the growing consolidation of outsourcing of logistics and the growth of the LSP market, Brekalo \& Albers (2016) report that the focus of research in the area has been on the positive aspects of relations between client companies and LSPs. In turn, the negative aspects have been neglected, which shows the need for more research on the topic. The negative side, according to them, is the conflicts caused by the relationship arising from quality in services, Key Performance Indicators (KPIs) not met, new costs and charges not always agreed in advance. Therefore, Gerbl et al. 
(2016) emphasize the importance of outsourcing monitoring, to avoid conflicts that lead to a deterioration of the relationship or even to understand its advantages and disadvantages better, thus building a more precise and assertive position in case the company changes its choice. Liu et al. (2015) argue that because the use of external resources increases the uncertainties regarding contracted operation and customer service, outsourced logistics is often viewed negatively by LSP users. Examples include the inability to meet specific logistics requirements or future growth needs, incompatibility between information systems, and safety-related issues. However, these authors also note that information sharing, and process coordination should be considered when companies exploit external resources because integration mechanisms, such as controls between firms, can leverage resources to create new capabilities between them. Thus, an LSP's ability to improve their competence, to meet the needs of the customer company, tends to contribute to the development and continuity of their services.

Over the last few decades, factors such as more expertise and more significant economies of scale have made it possible for LSPs to offer their customers better services at lower prices than these companies would be able to carry out on their own. However, prices have reached levels so low that further cost reductions are not a viable proposition to increase competitiveness, especially for companies based in high labour cost countries. According to Kersten \& Koch (2010), regardless of the price issue, the quality of LSP services has a positive influence on the maintenance of contracts and the success of their customer's business. This information is relevant to the competition among LSPs, as many of them assume that prices dominate it. This point shows that service providers who emphasize service quality are more likely to be successful than competitors with the sole concern of reducing costs. In parallel, for the customer companies, control over underutilized properties, structure and resources, which generate idle capacity, becomes a potential source of managerial inefficiency, and is relevant to the LSP to be aware of this relationship in their business.

Huo et al. (2015) conducted a study in which they analyzed the commitment of the relationship and logistical outsourcing, stating that they are related and jointly influence the outsourcing of logistics. LSP users can control the adverse effects of dependency by cultivating a proper relationship commitment with their providers. Therefore, outsourcing logistics managers should develop appropriate types of relationship commitment to deal with different types of dependency.

Specifically, the advancement of the LSP sector through mergers, acquisitions or capacity expansions without planning and a direct relationship with contracted businesses can impact its cash flow, especially in times of financial crisis, and considering a scenario of globalization and diversification of markets that can undermine management efficiency (Min et al., 2013). This position strengthens the importance of these providers to develop continuous and personalized service contracts that relate their competencies, assets and resources in an integrated way to the business of their medium and long-term clients. Overall, as reported by Prockl et al. (2012), the LSP market is characterized by a variety of different competitors in size, geographic coverage and service offerings.

Briefly, the classification criteria of LSP activities can be seen as basic, personalized and advanced. Process coordination is useful for basic outsourcing, while information sharing is useful for custom outsourcing. In order to effectively implement a so-called "advanced outsourcing", processes need to be coordinated and information shared between companies. This idea implies that the different services involved in the 
outsourcing of logistics processes will require sophisticated mechanisms to be developed. Liu et al. (2015) consider that basic and advanced outsourcing significantly improves operational performance, while customized outsourcing improves financial performance, showing evidence of the strategic functions of outsourcing logistics to LSP users.

Authors such as Hilletofth \& Hilmola (2010) question the impact of this outsourcing on supply chain management (SCM) and strategy and performance measures, as well as on the behavior of companies that outsource various functions with the same operator. These authors also present several factors that characterize the outsourcing of logistics processes, from the client company, such as:

- Lack of competence of the company to conduct its logistics services, such as warehouse management, inventory, fleet and distribution activities.

- Reaching new markets and improve customer service.

- Centralizing distribution and having flexibility in the scope of logistics activities.

- Reducing capital investments required for logistics activities.

- Having better information and communication technologies.

Thus, some LSPs, positioned at a service level more focused on the integration and coordination of activities in supply chains, called 4PL, can act as consultants managing other LSPs, such as conveyors, warehouses, etc. The study by Fabbe-Costes et al. (2009), based on a broad literature review in the area, reveals the opposite; that providers seem to be forgotten actors in studies regarding the integration and coordination of processes in supply chains.

It was in this "service vacuum" created by LSP that the concept of Lead Logistics Provider (LLP) or 4PL was born. LLP/4PL emerged on the foundations of the LSP and additionally offered solutions with integrated skills that aim at a way to leverage the supply chain. The LLP/4PL is a business process provider whose great advantage over LSP is their ability to add value and a more focused approach to customer needs. An LLP/ PL can manage an LSP, keeping the perspective of the freight company. The primary purpose is to maximize the benefit to the user (end customer). Thus, LLP/4PL is a supply chain integrator that synchronizes and manages its own organization's capabilities and technology with those of complementary service providers, delivering a broader, global solution for the client enterprise. The LLP/4PL thrives on leveraging the competencies of an LSP and business process managers with a more comprehensive and integrated solution for the chain. Moreover, they necessarily represent asset-free environments.

Studies by Huang et al. (2015) and Dircksen \& Magnin (2017), regarding the impact of outsourcing on delivery performance, cite coherence in the definition of tariffs as a preponderant for the management of the 4PL, creating a fair environment for carriers. One of the factors that emerged as preponderant for the management of the 4PL was the coherence in the definition of tariffs, creating a fair environment for freight companies. This relationship generally provides better performance and results to the 4PL client company. However, the authors point out that in a typical transport relationship between $4 \mathrm{PL}$ and manufacturer, $4 \mathrm{PL}$ acts as a neutral partner to manage the freight companies of the manufacturer and does not intervene in the charging process between them. Regarding consolidating loads from different manufacturers, the freight must be billed as a freight company. In this case, the 4PL would have to intervene in the collection process to distribute costs to manufacturers, which can be seen as compromising its neutral position. According to Cezanne \& Saglietto (2015), 
the expansion of the 4PL service is a trend that will continue, because SCM has been increasingly outsourced by companies. These activities require much specialized human capital to simplify productive operations and reduce their costs. As a result, the specific partnerships between clients and 4PL are multiplied, extending the boundaries of these providers.

With the advent of the internet, the LLP/4PL concept has thrived and proliferated as information and communication technology leverages and creates facilities in the relationship between supply chain agents, and a broad field for the formation of alliances and consortia (Win, 2008). This same author suggests the following attributes in the relation of the $4 \mathrm{PL}$ with their client companies:

Managing the activities of various logistics providers;

Having insight into processes related to the integration of the supply chain;

Having competence in cost management;

Having a good understanding of the companies and the segment in which they offer their services;

Being able to operate at operational, tactical and strategic levels;

Managing and coordinating day-to-day logistics in the supply chain;

Being accustomed to accounting;

Coordinating and fostering relationships within the supply chain;

Managing uncertainties between supply and demand;

Conducting change and improvement processes;

Having rigour when executing the processes;

Having experience in global supply chain management.

According to Mehmann \& Teuteberg (2016), the highest optimization potential of these models was detected in the 4PL-managed cooperative transportation planning area, reducing redundant work and minimizing information flow delays. However, new questions arise not only from using synergies that these providers may offer, but also from possible over-prices, or administrative fees that could be avoided. That is, the benefits of this model do not appear very clearly yet, or even they lack better understanding or more apparent operational structuring that these providers tend not to generate surcharges or over-pricing, as some understand they might. Furthermore, the existing doubt can be much more a matter of the insecurity of contracting managers than the obtained results, or even the measurement existing in the relationship does not give them the necessary security to maintain and consolidate this model.

Foerstl et al. (2016) also evaluate mixed outsourcing, which they call a hybrid, and raise concerns about the impact of insourcing on firms and even economies, as in the case of Asian countries. In this specific case, the maturity of logistics outsourcing lies in the fact that the assets represent substantial investments or even some systems required for routing, cargo order, loading and stocking represent a great deal in the company's business. Therefore, this alternative suggested by the authors may be a compromise that leaves the company in a more comfortable position if it wants to reverse decisions. The question that arises, in this case, is the so-called specialization and focus that appears as a strong component in the reason of outsourcing logistics.

Marasco (2008) also reports that one of the challenges in trying to assess the literature on LSP is the lack of a single consistent definition of the concept. Many definitions and interpretations about LSP can be found in the literature, that is, the 
terminology in this field is not always consistent. In some cases, LSP is used as a label for traditional transport and storage service. In contrast, in other cases, the term is used to describe more complex outsourcing that can cover all the logistics processes of a company or chain of supplies. Moreover, it mentions different definitions of LSP, such as:

- The LSP involves using external companies to perform logistic functions that have traditionally been performed within an organization. The functions performed by the service provider company can cover all the logistics processes or some activities within these processes;

- The LSP seems to be distinguished from the traditional outsourcing of logistics functions when it includes providing a wide range of services, a long-term duration, developing efforts with its customers in the process of cooperation and personalization of logistics solutions, working on a vision of equitable sharing of benefits and risks, and incorporating strategic activities, not just operational and tactical;

- The LSP can be seen as an interface between interfaces in supply chains, where logistics services are offered, from the basic to the personalized ones, in a more or less long-term relationship, to be more productive and efficient.

According to a study carried out by Ferreira et al. (2016), LSPs in Brazil present a misalignment between the proposed parameter of value and strategic control, reinforcing the view that they lack better definition in the scope and focus of the services offered. According to the authors, it can be noted that, in order to guarantee "superservices", large LSPs use the integrated management of their portfolio. In contrast, medium logistics operators use portfolio optimization and management of strategic alliances as control elements strategic. Small logistics operators, however, use the specialization of logistics operations and specialization by customers. For them, the LSP can be understood as:

A - The large LSPs concentrating their attention on super-services (continuous operations and large volumes), characterized by:

- Integration of their service portfolio, offering complete service packages; and

- For the integrated management of their portfolio, having synchronization between the various services, in order to increase the customers' perception of value.

B - Medium LSPs focusing their attention on convenience services, characterized by:

- Optimizing the service portfolio, as they have fewer services, and trying to combine them as much as possible to increase their margins; and

- Management of strategic alliances, increasing their portfolios based on services that their partners are able to offer and thus increase their competitiveness visà-vis the large LSPs.

C- Small LSPs focusing their attention on personalizing services and are characterized by:

- Logistics operations specialized in one or a few forms of logistics services;

- Specialization by clientele, focusing on specific niche demands for logistical services. 


\section{The importance of websites}

The combination of information and communication technologies has generated changes throughout society, connecting companies and their customers. Websites provide effective communication and information channels among organizations. Today, many managers rely on their company's website as their primary channel of communication with customers, suppliers, and the community at large. Thus, companies need to provide information that helps customers understand their product offerings and supports customer decision-making. The quality of the information refers to the accuracy, completeness and presentation of this information posted by the service providers. For some organizations, websites serve as an information bank for interested parties. For others, websites offer transaction capabilities by providing additional tools to service customers. Since websites act as an essential point of contact between companies and their customers, it is critical to provide the right type and quality of information and interactions to satisfy customers. Understanding the essential attributes of a website and the information they provide is critical to business success, as it can be used to enhance online communication between companies and their customers (Thaichon \& Jebarajakirthy, 2016). On the other hand, as Freitas et al. (2016) explain, the agility of information, such as those provided by a website, with instantaneous data will contribute not only to generating information but also to planning the supplier-consumer interaction. According to them, a key factor is that there will no longer be centralized control.

The quality of the website is defined as the ability to provide information and perform the promised service consistently and accurately. Information content refers to information that gives the public a better understanding of the services or purchase objectives. In general, websites should provide a wide range of information in a format that is easy to understand and follow. The quality of the information should be judged according to the customer's perception of the information provided. The information must be accurate, timely, and relevant to users. Besides, company information must be supportive, reliable, complete, consistent and appropriate. In other words, the information provided must be current and necessary to customers (Pearson et al., 2007).

Moreover, the quality of the website influences the level at which customer expectations are met. When customers visit a company website, they expect to obtain unique and appropriate information. Lack of information makes it difficult for customers to receive the correct message. Companies need to be aware of the kind of information that should be on their websites and avoid information that distracts customers from decision making (Galati et al., 2016; Pearson et al., 2007).

In order to increase customer value, a company can add more benefits or reduce the costs associated with the service and use of the service. Additional benefits could take the form of superior information quality and protected privacy. Customers can evaluate the value of services directly or indirectly through information provided by the websites (Thaichon \& Jebarajakirthy, 2016). This is the case of a WMS (Warehouse Management System), which has high investment and can bring advantages to customers when available for consultation on the websites (Assis \& Sagawa, 2018).

In a strategic vision of SCM or business networks, Nunes \& Mollo (2015) consider using business integration via websites as a competitive advantage. According to research by these authors, the result confirms that websites are potential support for SCM or networks of companies, improving relationships, information exchange and operations between the companies involved. In turn, Ribeiro et al. (2018) in a study on 
TMS (Transportation Management Systems) highlight the high cost of integration and relationship tools through websites, their advantages and compatibility in sharing with customers, which can be reliable impediment logistics service providers to integrate the websites with their customers further.

\section{Analyzing the main attributes for LSPs}

Table 1 summarizes the characteristics that define an LSP, according to the most evident skills in theory presented above. In turn, these skills led to field research and served as a basis for discussing the points that guide the understanding of the types of logistical outsourcing adopted by LSPs in Brazil. These skills also support the argument regarding the ability of LSPs to integrate into supply chains by positioning and offering services that they offer on their websites.

Table 1. Attributes researched on the LSP website.

\begin{tabular}{|c|c|c|c|}
\hline QUALITY & COMPETENCES & $\begin{array}{c}\text { INTEGRATION \& } \\
\text { 4PL }\end{array}$ & $\begin{array}{c}\text { SERVICE - } \\
\text { WAREHOUSE }\end{array}$ \\
\hline Elementary & Primary & YES & Storage \\
\hline Basic & Basic & NO & Support management \\
\hline Structured & $3 P L$ & & Picking \\
\hline Advanced & 3PL Integrated & & Fractionation \\
\hline & $4 \mathrm{PL}$ & & Packing \\
\hline & & & Others \\
\hline & & & In-house \\
\hline $\begin{array}{c}\text { SERVICE - } \\
\text { TRANSPORT }\end{array}$ & CHARACTERISTIC & SEGMENT & $\mathrm{ICT}^{\star}$ \\
\hline Primary & Storage & Open & WMS (1) \\
\hline Distribution & Transport & 1 Sector & TMS (2) \\
\hline Cross & $\begin{array}{c}\text { Ports and } \\
\text { Commodities }\end{array}$ & 2 Sectors & Sist. Management (3) \\
\hline Several & Distribution & 3 Sectors & Intranet (4) \\
\hline Support Management & Express Delivery & 4 Sectors & Automation (5) \\
\hline \multirow[t]{4}{*}{ Total Logistics } & In-house & 5 Sectors & $(1)+(2)$ \\
\hline & Multifunctionality & 6 Sectors & $(1)+(2)+(3)$ \\
\hline & 4PL & 7 Sectors & $(1)+(2)+(3)+(4)$ \\
\hline & & 8 Sectors & $(1)+(2)+(3)+(4)+(5)$ \\
\hline
\end{tabular}

*ICT (Information and Communication Technology).

The positioning adopted on the websites by the LSP helps to understand the quality of the services offered and the ability to serve them. A vision can be established regarding the quality of the sites according to the elements discussed in the previous chapter.

\subsection{Classification of Logistic Service Providers according to their competences}

4PL - It coordinates other operators in the customer's chain. Defined by long-term contracts and robust strategy in the management of logistics services. It is an integrator in the supply chain that synchronizes and manages resources, capabilities and their 
organization technology with the complementary service provider to offer a full and comprehensive solution to the customer.

3PL integrated - It performs several activities and demonstrates strong interaction with its customers, supported by contracts and committed to the businesses in which it is inserted. It is marked by commitment and relationship with its customers.

$3 \mathrm{PL}$ - It provides several activities in its portfolio, with clear intent to execute and operationalize contracted services regardless of continuity or contractual negotiation. Usually, services include activities such as warehouse management, inventory, freight and distribution.

Basic - it demonstrates performing more than one activity, but very concentrated in storage and transport.

Primary - it is characterized by performing a single activity. Usually only warehouse or only transportation.

Unclassified - it cannot clearly define the logistical business proposed on the site.

\subsection{Website rating}

Advanced Site - It articulates a vision of supply chain operations, helps the customer understand how the integration of different activities can contribute to the business. The provision and presentation of information demonstrate knowledge about logistics operations and the supply chain, generating confidence for those who navigate, as well as showing the benefits of having a single LSP. This clearly shows the importance of services and Information Technology in the provision of services. Access is usually by "access tabs" on the home page, where you can easily navigate and obtain the information you need to understand the different types of services and possible supply chain integration. It is clear that the LSP has an understanding of its role in supply chains and how it can help the client. The discussion and clarification of the services are clear, with strong support in images or links.

Structured website - it demonstrates several services, attributes and competencies of the LSP. The description of the activities is evident, and the examples and presentation of the website show competence in the proposed activities. What is usually little explored is the integration and relationship of services in the supply chain, as well as service tabs and links, although evident, offers little interaction with the user, appearing a relatively restricted provider in their competencies.

Basic website - it exposes the different services of an LSP without valuing competencies. The services are exposed without any relation of value or importance, only clarifying that they can perform that activity. Navigation is boiled down to information on the main page, with some interaction with service tabs.

Primary website - It presents the company and practically does not relate its logistics competences, it only opens the information in its main screen, with little or almost no interaction with service flaps.

\subsection{Integration capacity}

According to a study by Marchesini \& Alcântara (2014), most of the activities carried out by the LSP are considered as basic, demonstrating coherence in the research because new or innovative activities are irrelevant. However, for the authors, such activities can be performed within the business process spheres, in the sense that 
logistics is no longer an isolated business function but integrated with other areas and critical processes of the supply chain business. This position strengthens the idea of integrating logistics services into the activities of the supply chain.

The ability to take on a range of services related to existing processes in the customer's supply chain by combining operational execution with the support of information and technology interaction characterize the integration process. This position can occur both for the LSP with advanced outsourcing characteristics, whose main characteristic is in the coordination of processes and information sharing. This required a mechanism and a more sophisticated management model about the basic LSP model aimed at simple primary service delivery such as transportation and warehouse. The perception of integration capacity is in understanding the characteristics and behaviour of the LSP, as reported by Liu et al. (2015) that the LSP can offer a customized outsourcing model.

In this aspect, the intention is to identify how the LSP presents itself on the Internet, if it demonstrates the ability to perform different tasks with strong administrative support, but also can characterize a relationship with process management in a 4PL model. These characteristics can be manifested by understanding the main activities highlighted on their website, how it positions itself for the market and how it can be seen by those who intend to hire an LSP, based on the vision presented on the website.

\subsection{Types of services offered, segments served, and technology adopted}

The types of services offered or characterized, as well as the skills shown on the websites help to understand at which level of integration the LSPs are positioned. This characteristic, coupled with the capacity to serve different regions of the country, as well as how to position itself in the different market segments, helps to understand the integration capacity offered by the LSP. It is known, as already discussed in the literature review, that regional amplitude is a favorable factor for the provision of integrated services. However, the diversification of business segments does not help in the specialization of the LSP.

Information and Communication Technology (ICT), closely linked to the provision of services, whether in storage and transportation activities or many other processes, has become a preponderant factor in the carrying out and supply of services and is characterized as the main instrument favorable to integration.

\section{GAPS literary (LSP $x$ internet)}

Based on literary research, some observations and positions discussed by this study were rarely mentioned. Thus, this article intends to contribute to a better understanding of these possible gaps:

- Although the discussion between ICT and logistical integration are essential factors in the context of LSPs (Sharma \& Choudhury, 2014), the literature does not discuss whether commercially LSPs demonstrate this on their websites (Freitas et al., 2016; Stevens \& Johnson, 2016).

- From the perspective of their websites, the position that the LSP performs different activities (Singh Bhatti et al., 2010; Kersten \& Koch, 2010), becoming a differential for them, is not discussed in the literature. The literature also does not discuss how 
the LSP can be classified (2PL, 3PL, 4PL) from the data extracted from its website (Prockl et al., 2012; Foerstl et al., 2016) .

- The research literature (Liu et al., 2015, Marchesini \& Alcântara, 2014) cites the importance of differentiation in activities and the concentration of primary services (transportation and warehousing). However, there is still little emphasis on the movements (in the competitive market) driven by LSPs and their segmentation by the industrial sector.

\section{Methodology}

The empirical research started by searching for the main logistics service companies in Brazil. Information from class associations, ranking of magazine and journal sites recognized in the sector (such as Revista Exame-Abril, Revista Tecnologística, Guia do Transportador, Brazilian Association of Logistic Operators and Brazilian Association of Logistics) was used. Table 2 summarizes this step.

Table 2. Website of the sources researched.

\begin{tabular}{cc}
\hline Sites of Magazines and Associations surveyed & \\
\hline Revista Tecnologística (2016) & 135 \\
\hline Guia do TRC (2015) & 73 \\
\hline Revista Exame (2014) & 45 \\
\hline ABOL (2016) & 23 \\
\hline ABRALOG (2016) & 64 \\
\hline Total of companies mentioned & $\mathbf{3 4 0}$ \\
\hline
\end{tabular}

In the first classification a general list with 340 companies was obtained. In the first review seeking repeat and non-business-related logistics services, there were 240 companies. Having this list, we set out to search directly on the Internet websites of each of them. After accessing all the websites related to each company, 153 companies were reached for which the research could be applied. There are various reasons for this reduction. Among them is the fact that the company or its website does not exist, that the company is a branch of a larger corporation not related to logistic business, to be a provider of services like software, and to be a company that provides products and services for LSP, insurers and consultancies.

For this final list of LSPs, each website was carefully researched according to the attributes discussed in the previous chapter. The investigation consisted of three stages of analysis, classifying the various factors related to the mentioned attributes as the analyses consist of interpreting the website performed by different researchers, the first and second analysis collected and the data tabulated according to the information obtained. After this stage, the two analyses were compared, and the companies were found to have divergences. A third analysis was carried out through the interaction of the two researchers, closing the data for the final tabulation of the information. It should be noted that these two researchers involved in the research individually have more than two decades of experience and experience in the field, both as consultants and professionals working in industrial companies or providers of logistics services. 


\section{Analysis of information}

According to the site's quality criteria, the survey concluded that 70 companies are at the basic level. In other words, the website is limited to placing the company in a list of services related to transportation and warehouse, without any articulation with possible integration in the customers' supply chain. As can be seen in Figure 1, 20 companies were below that, at an elementary level, where they only present the company, describe the services and their contacts. At the structured level there are 53 companies and in these the integrated relationship with customers can be clearly demonstrated. At the advanced level, there are 10 companies and in these we can highlight the clear competence in the integration with the client companies. Thus, it is possible to perceive that the Brazilian LSP market, about the positioning that they adopt in their websites, still has, in most cases, a significant development path for articulating integrated services with their customers. More structured companies (prepared to disseminate the concept of integrated services in the supply chain have a good representation $(41 \%)$. Despite the representativeness, there is still a long way to be overcome by the deficiency existing in the others $(59 \%)$, since the vision of an LSP, in its conception, considers the practice of the concepts expected at the structured level up.

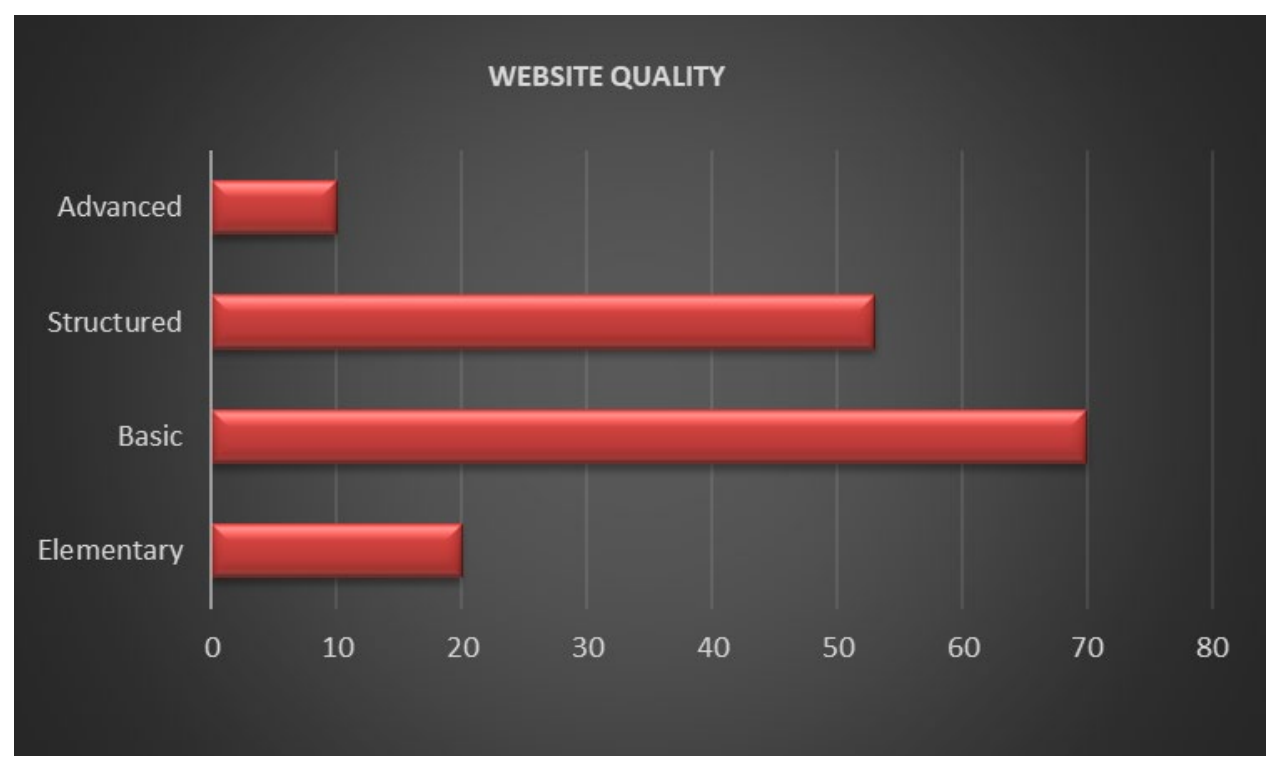

Figure 1. Website quality.

Regarding the description of the competencies presented by the companies to characterize their services, it can be said that many companies are classified as providers of freight and storage, but they also usually add other services to customers. As a result, it can be concluded that the website is not being explored as it could, as shown in Figure 2. In this figure, it can be seen that 32 companies present themselves as being in the primary and basic stage ( 29 and 3 , respectively), but the research shows that in fact 50 are seen as being in that stage. At the most advanced level (3PL full, integrated and $4 \mathrm{PL}$ ), companies highlight the attributes related to the service model in their websites (121 companies). However, it was considered that a smaller number $(103=85 \%)$, in fact, establishes a good correlation between the attributes desired for these providers and what they describe on their websites. 


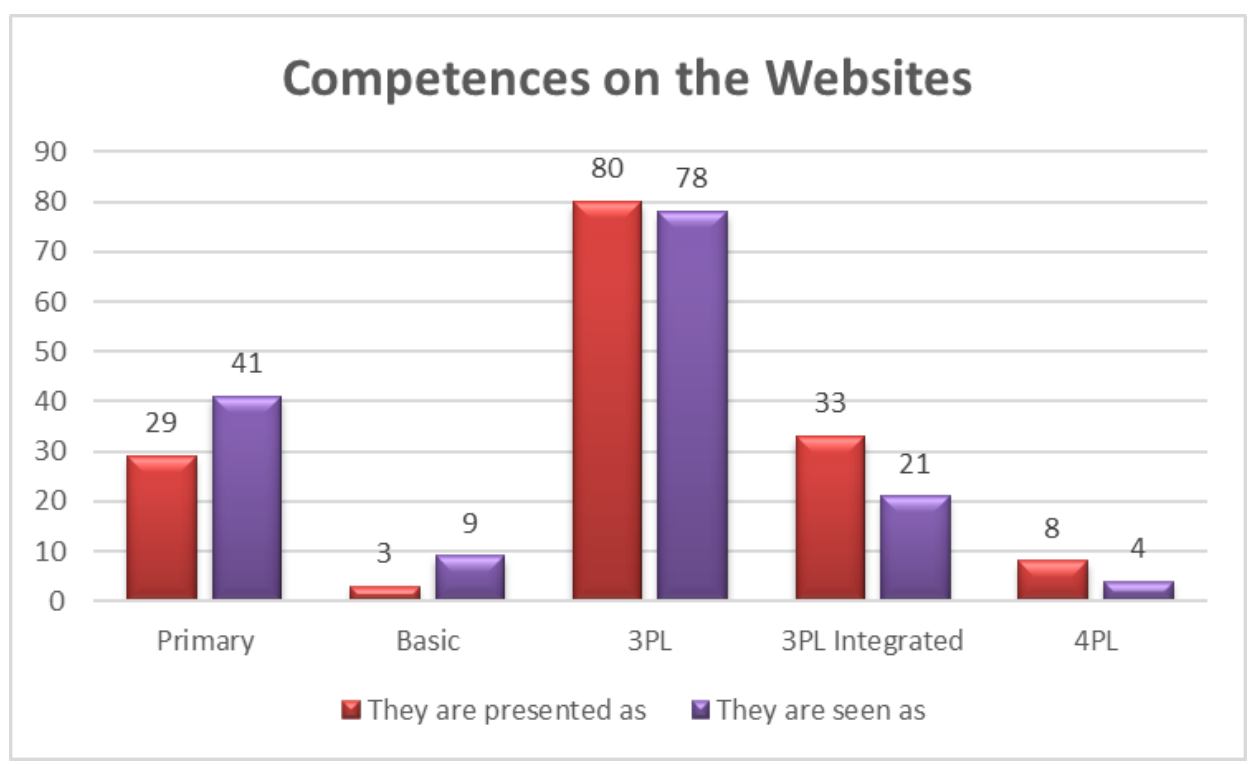

Figure 2. Competencies on the websites.

On the other hand, when it restricts the view on the providers that meet the requirements of integrated LSPs and the service offered in the 4PL business model, it is noticed that about $8 \%$ meet the $4 \mathrm{PL}$ criteria, and $20 \%$ the LSP integrated, as shown in Figure 3. That is, considering the 4PL model as a differentiated commercial form of logistics services, which traditional LSP competence can migrate to, the field is representative. However, many LSPs restrict themselves to their competencies and do not adhere to this type of model. Thus, with the vision of $20 \%$ of companies responding to integration competency, one can perceive the potential for the market of services offered by the LSP to follow in this direction.

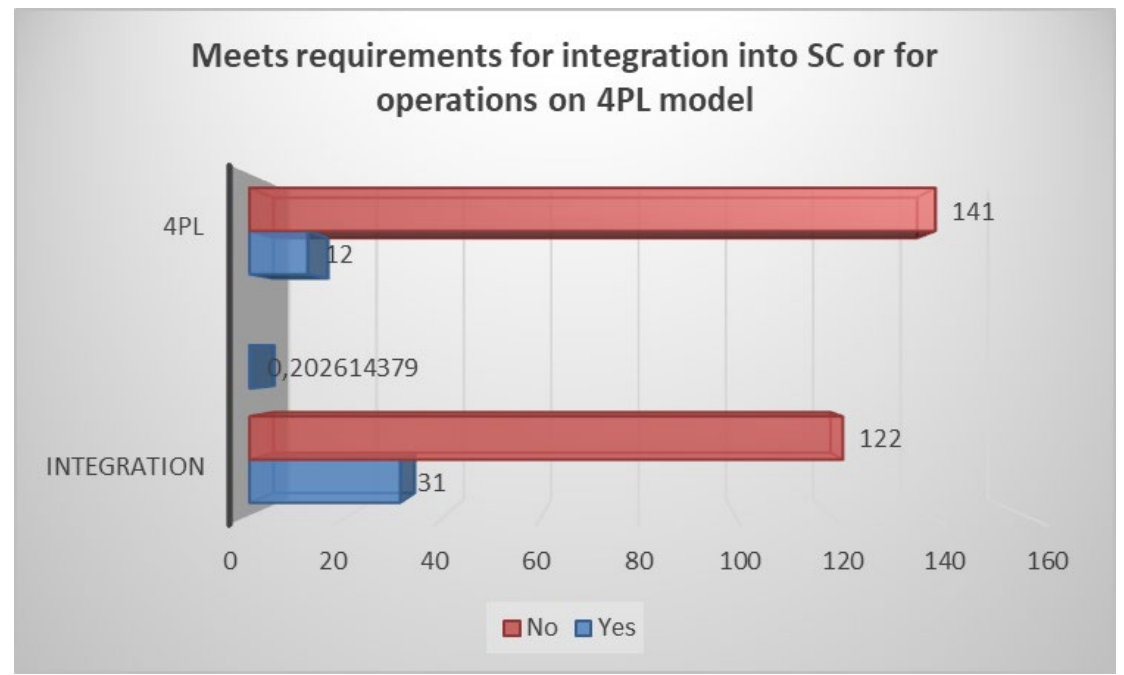

Figure 3. Integration requirements in the supply chain (SC) and 4PL model.

When observing the primary services of the LSP, transport and warehouse/storage, many of the activities related to these services are offered by most of the websites of 
these providers, making it clear that there is no strong diversification of the offer of storage and transport services, as shown in Figures 4 and 5 .

It can also be observed that stocking, picking, and fractionation of products stand out as fundamental activities in storage, accompanied by the support management that these activities usually require, as shown in Figure 4.

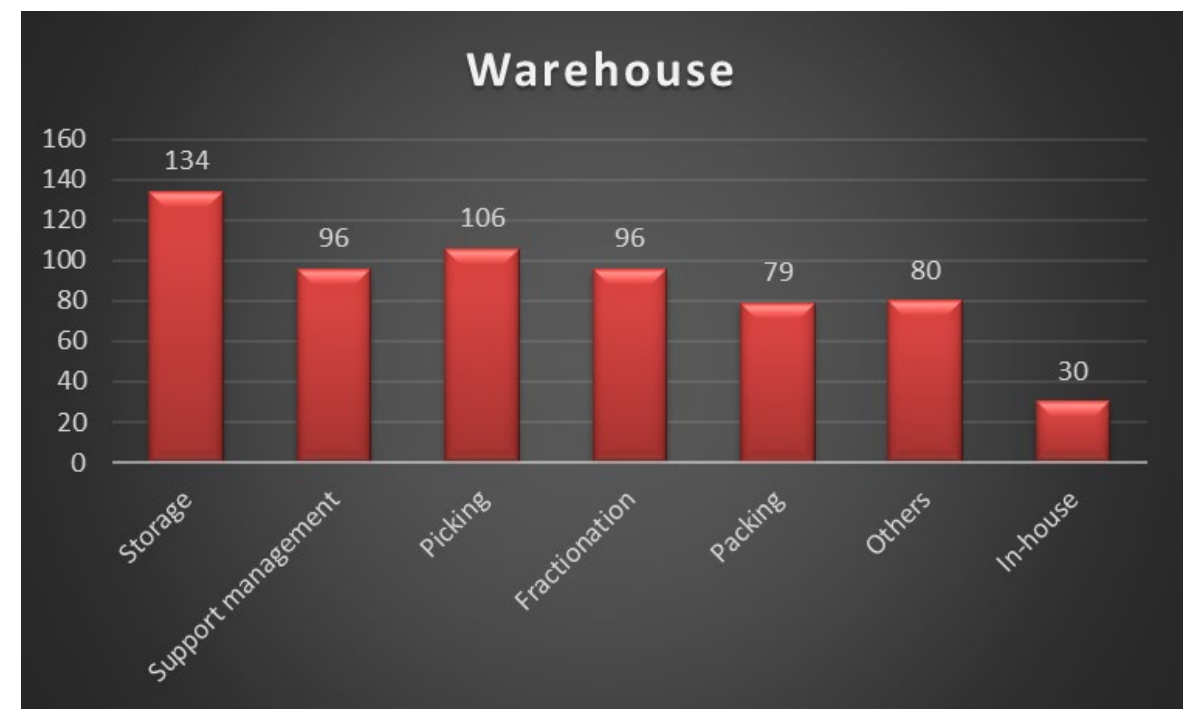

Figure 4. Primary Service: Warehouse.

Based on Figure 5, the same occurs in the transport area, with primary transport, distribution and cross-docking as main activities, also accompanied by support management, which is much demanded by customers who want to track their loads and deliveries.

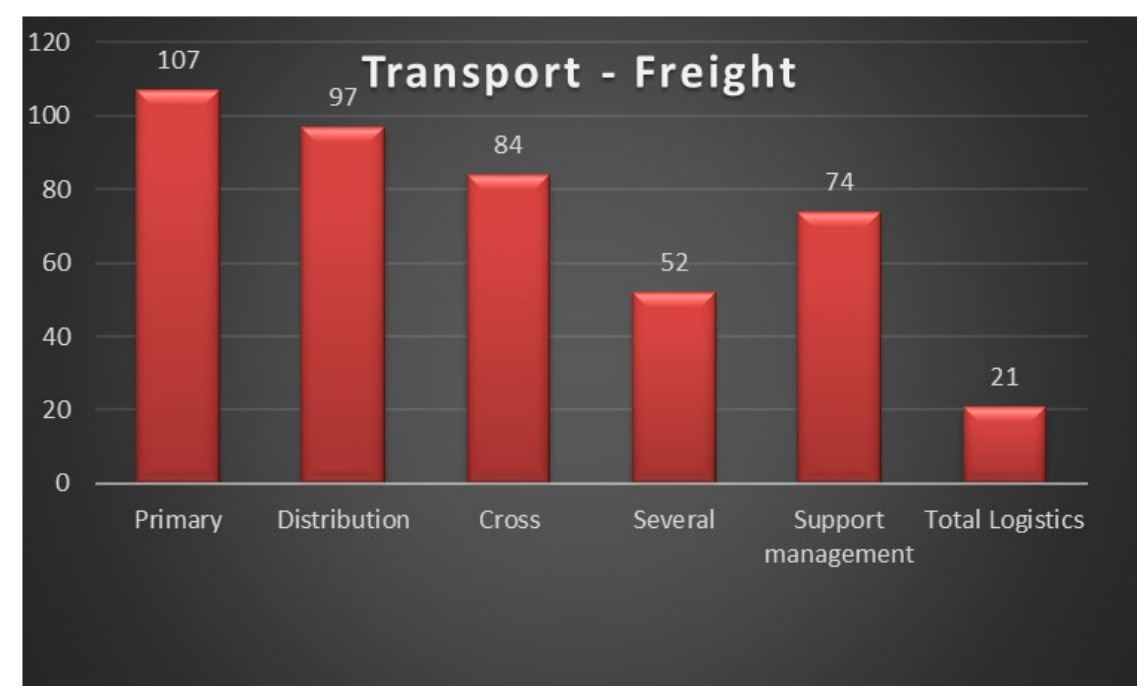

Figure 5: Primary Service - Transport

When analyzing which activities the company is best characterized by using the information mentioned on its website, it can be seen in Figure 6 that transportation and 
storage activities are predominant. Then there are the activities of ports and distribution, with a strong emphasis on companies that mention on their websites a wide range of skills to characterize their services.

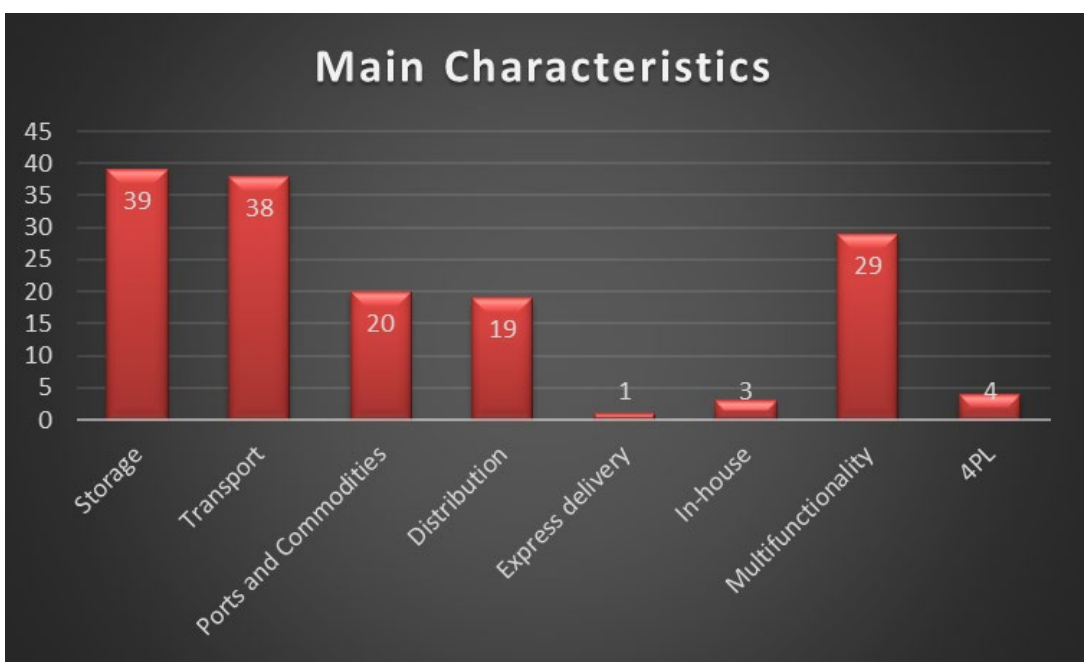

Figure 6. Main characteristics of an LSP.

The same trend occurs with the market segment with which they position themselves on the websites. It can also be observed that the companies present themselves as potentially prepared to operate in any type of market segment, that is, they can serve any type of customer. Those who make it clear that they serve a sector only come in second. This information, shown in Figure 7, shows how the LSP market does not yet realize the importance of segmentation and specialization in specific markets.

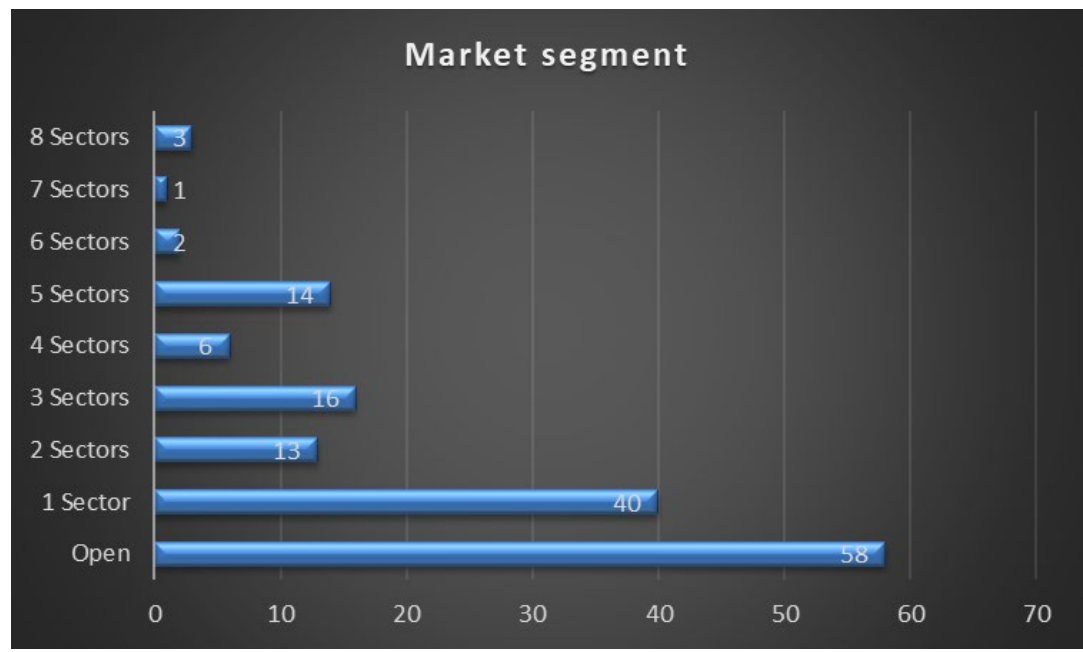

Figure 7. Market Segment.

In the question about using information and communication technology, it can be pointed out that the vast majority of the LSPs already have the basic tools that support their businesses. These involve systems such as WMS and TMS, which support 
warehousing and transport activities, usually backed by an ERP capable of supporting the business and making the significant integrations that tend to occur on the intranet. This view is based on the combination of these tools, as shown in Figure 8. On the other hand, using automated systems does not appear as a differentiating factor in the websites, highlighted in just over $10 \%$ of the websites surveyed.

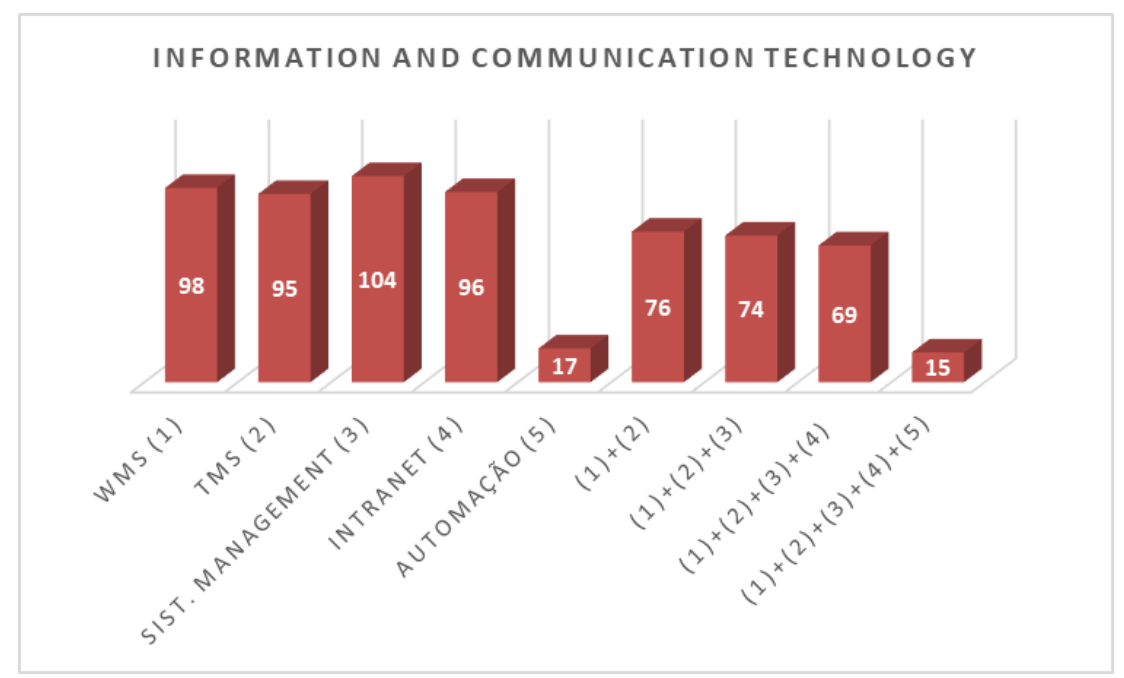

Figure 8. Information and Communication Technology.

\section{Final comments}

The theoretical discussion points to the importance of websites for organizations, considering that many consider them as their main communication channel. The combination of services offered with a focus on the activities they carry out and dominate needs to be perceived by those who seek information on the website. Thus, companies providing logistics services need to provide information that helps their potential customers understand their product offerings and thus support customer decision-making. The research made clear that most (59\%) of the LSPs in Brazil cannot articulate and present their competences clearly to those who consult their sites. This may include detailed descriptions and different other information, which are no longer presented or better detailed. When analyzing the sites in order to understand the LSP's ability to articulate in its customer supply chain, offering and assisting in different activities, the number is not very significant (only $7 \%$ ), making it clear that this market is still at a stage of development. LSP appears to be more concerned with executing activities than with integrating with their customers and the quality of information on their sites. And it can generate trust, establish a broad vision of the services offered, demonstrate the ability to perform what was agreed, etc.

It is also noted that most of the services offered by the LSP can be classified as simple transactions and repeated transactions. The view of building agreements, such as outsourcing, partnership and integrated services agreements, are more restricted and appear in $27 \%$ of the LSPs investigated. This confirms the position of Singh Bhatti et al. (2010) that the commoditization of LSP services has contributed to undoing the purpose of $3 \mathrm{PL}$ and inducing customer companies to consider further whether or not to outsource. 
It is also possible to corroborate the literature's claim that the scope of LSP services is expanding (Kersten \& Koch, 2010) because most sites present a view that LSPs can do many different activities. On the other hand, as they present themselves capable of doing any activity in different segments, it contradicts the view of authors such as Min et al. (2013). The latter defended the specialization and integration of the customer's business into longer-term contracts. It can also be considered that website analysis leaves the impression that the investigated companies are more focused on offering their services and not on building a long-term relationship with their customers.

The integration of services in the supply chain observed in the sites appears in $20 \%$ of the LSPs. The majority of LSPS $(+60 \%)$ are supported by information and communication technology in storage and transport services. The internet portal as a communication and relationship channel can be considered a key point for improving the offer of integrated services. This is because LSPs can incorporate the role of integrating agents and better work relationships through this channel. It is also known that a relevant factor for this is the incorporation and intensive use of information and communication technology in supply chain management. In turn, it can be observed that $45 \%$ of the companies researched have systems capable of potentially responding to such demands. One can then consider that what exists is a lack of better conceptual positioning of these providers in the market and their potential customers.

Finally, based on the research carried out, the following characteristics of logistical outsourcing in the country can be highlighted:

- Sale of specific services, based on transactional execution, not supported by a continuity relationship

- The predominance of executing primary logistics services, such as transport and storage.

- Transport and storage services are supported by technological support systems (such as ICT), signalling that the segment in terms of technology has been advancing.

- The relationship with customers supported by the Internet is also a reality, in which websites are an important channel to relate to customer companies and the market in general.

- In general, there are few websites structured to explore and articulate the logistics services in the supply chain.

- Many LSPs are positioned within a broad scope of service and very open segmentation. It is understood that they consider themselves capable of performing many activities in different places and segments. However, this can give the customer an inverse perception of incompetence.

- The supply of integrated services in supply chains is not representative, not for technological constraints, but much more for a conceptual positioning of companies.

The study also identified about $5 \%$ of providers in the 4PL model. Some of which offer the service in the 4PL model, but also offer services such as a traditional 3PL. This position in Brazil does not match the position of Singh Bhatti et al. (2010) when they affirm that 4PL thrives, taking advantage of the skills of LSPs and business process managers, to offer more comprehensive and integrated solutions in the supply chains. These authors also claim that 4PLs essentially constitute asset-free organizations, which was not fully observed in the study. According to these same authors, with the advent of the Internet, the 4PL concept has found more customers. 
The 4PL concept has grown as ICT has leveraged and created various forms of relationships between companies in a supply chain. However, in the case of this research, this was not observed, given that the adoption of $4 \mathrm{PL}$ is still not very representative.

Based on the research carried out, one can consider the consolidation of LSP and the emergence and growth of companies in the 4PL model seem to be entering an inverse cycle. There are signs of insourcing in the case of LSP and an unrepresentative advance of 4PL. Thus, future investigations are suggested to help understand and better analyzed the phenomenon.

In turn, an empirical study based on data available on websites does not allow a higher generalization of their findings. However, it is considered here that it can provide exciting insights, thus helping to identify better and understand how LSPs have positioned themselves in the market and their customers in the supply chains.

\section{References}

Assis, R., \& Sagawa, J. K. (2018). Avaliação da implantação do Sistema de Gestão de Armazém em uma empresa multinacional do ramo de acionamentos. Gestão \& Produção, 25(2), 370-383. http://dx.doi.org/10.1590/0104-530x3315-18.

Associação Brasileira de Logística - ABRALOG. (2016). Lista de associados. Retrieved in 2016, March 28, de www.abralog.org.br/website/associados/

Associação Brasileira de Operadores Logísticos - ABOL. (2016). Lista de associados. Retrieved in 2016, March 28, from www.abolbrasil.org.br/associados

Brekalo, L., \& Albers, S. (2016). Effective logistics alliance design and management. International Journal of Physical Distribution \& Logistics Management, 46(2), 212-240. http://dx.doi.org/10.1108/IJPDLM-08-2014-0201.

Cezanne, C., \& Saglietto, L. (2015). Redefining the boundaries of the firm: the role of 4PLs. International Journal of Logistics Management, 26(1), 30-41. http://dx.doi.org/10.1108/IJLM-06-2012-0054.

Dircksen, M., \& Magnin, G. (2017). Evaluation of synergy potentials in transportation networks managed by a fourth party logistics provider. Transportation Research Procedia, 25C, 824841. http://dx.doi.org/10.1016/j.trpro.2017.05.460.

Fabbe-Costes, N., Jahre, M., \& Roussat, C. (2009). Supply chain integration: the role of logistics service providers. International Journal of Productivity and Performance Management, 58(1), 71-91. http://dx.doi.org/10.1108/17410400910921092.

Ferreira, C. C., Rodrigues, L. C., Oliveira, M. A. M., \& Riscarolli V. (2016). Controle estratégico e proposta de valor no modelo de negócio de operadores logísticos com sede no Brasil. Revista Ibero-Americana de Estratégia - RIAE, 15(4), 91-104.

Foerstl, K., Kirchoff, J. F., \& Bals, L. (2016). Reshoring and insourcing: drivers and future research directions. International Journal of Physical Distribution \& Logistics Management, 46(5), 492-515. http://dx.doi.org/10.1108/IJPDLM-02-2015-0045.

Freitas, M. M. B. C., Fraga, M. A. F., \& Souza, G. P. L. (2016). Logística 4.0: conceitos e aplicabilidade: uma pesquisa-ação em uma empresa de tecnologia para o mercado automobilístico. Caderno - PAIC, 17(1), 237-261.

Galati, A., Crescimanno, M., Tinervia, S., \& Siggia, D. (2016). Website quality and internal business factors: an empirical investigation in the Italian wine industry. International Journal of Wine Business Research, 28(4), 308-326. http://dx.doi.org/10.1108/IJWBR-08-2015-0026. 
Gerbl, M., Mclvor, R., \& Humphreys, P. (2016). Making the business process outsourcing decision: why distance matters. International Journal of Operations \& Production Management, 36(9), 1037-1064. http://dx.doi.org/10.1108/IJOPM-04-2014-0192.

Guia do TRC. (2015). Ranking dos maiores Operadores Logísticos 2015. Retrieved in 2016, March 28, de www.guiadotrc.com.br/mercado/ranking_operadorlog2010.asp

Hilletofth, P., \& Hilmola, O. (2010). Role of logistics outsourcing on supply chain strategy and management - Survey findings from Northern Europe. Strategic Outsourcing, 3(1), 46-61. http://dx.doi.org/10.1108/17538291011023070.

Huang, M., Ren, L., Lee, L. H., \& Wang, X. (2015). 4PL routing optimization under emergency conditions. Knowledge-Based Systems, 89, 126-133. http://dx.doi.org/10.1016/j.knosys.2015.06.023.

Huo, B., Liu, C., Kang, M., \& Zhao, X. (2015). The impact of dependence and relationship commitment on logistics outsourcing: Empirical evidence from Greater China. International Journal of Physical Distribution \& Logistics Management, 45(9/10), 887-912. http://dx.doi.org/10.1108/IJPDLM-04-2015-0109.

Instituto de Logística e Supply Chain - ILOS. (2014). Terceirização Logística no Brasil 2014. Retrieved in 2016, March 1, from http://docplayer.com.br/16708438-Brochura-panoramailos-terceirizacao-logistica-no-brasil-2014.html

Kersten, W., \& Koch, J. (2010). The effect of quality management on the service quality and business success of logistics service providers. International Journal of Quality \& Reliability Management, 27(2), 185-200. http://dx.doi.org/10.1108/02656711011014302.

Lieb, R. (2008). The year 2007 survey - provider CEO perspectives on the current status and futureprospects of the third-party logistics industry in the Asia-Pacific region. International Journal of Physical Distribution \& Logistics Management, 38(6), 495-512. http://dx.doi.org/10.1108/09600030810893535.

Liu, C., Huo, B., Liu, S., \& Zhao, X. (2015). Effect of information sharing and process coordination on logistics outsourcing. Industrial Management \& Data Systems, 115(1), 4163. http://dx.doi.org/10.1108/IMDS-08-2014-0233.

Marasco, A. (2008). Third-party logistics: a literature review. International Journal of Production Economics, 113(1), 127-147. http://dx.doi.org/10.1016/j.jpe.2007.05.017.

Marchesini, M. M. P., \& Alcântara, R. L. C. (2014). Proposta de atividades logísticas na gestão da cadeia de suprimentos (SCM). Produção, 24(2), 255-270. http://dx.doi.org/10.1590/S0103-65132013005000053.

Mehmann, J., \& Teuteberg, F. (2016). Process reengineering by using the 4PL approach: a case study on transportation processing in the agricultural bulk logistics sector. Business Process Management Journal, 22(4), 879-902. http://dx.doi.org/10.1108/BPMJ-12-2014-0119.

Min, H., DeMond, S., \& Joo, S. (2013). Evaluating the comparative managerial efficiency of leading third-party logistics providers in North America. Benchmarking, 20(1), 62-78. http://dx.doi.org/10.1108/14635771311299498.

Nunes, R. M. S., \& Mollo, M., No. (2015). Análise da contribuição do business to business na gestão de cadeias de suprimentos. Revista GEPROS. Gestão da Produção, Operações e Sistemas, 10(2), 157-172.

Pearson, J. M., Pearson, A., \& Green, D. (2007). Determining the importance of key criteria in web usability. Management Research News, 30(11), 816-828. http://dx.doi.org/10.1108/01409170710832250.

Prockl, G., Pflaum, A., \& Kotzab, H. (2012). 3PL factories or learn stats? Value-creation modelsfor 3PL service providers. International Journal of Physical Distribution \& Logistics Management, 42(6), 544-561. http://dx.doi.org/10.1108/09600031211250587.

Revista Exame. (2014). As Melhores Empresas do Brasil em 2014. Retrieved in 2016, March 28, from http://exame.abril.com.br/negocios/melhoresemaiores/2014/ 
Revista Tecnologística. (2016). Mercado Brasileiro de Operadores Logísticos. Revista Tecnologística, 196, 67-133. Retrieved in 2016, March 28, from www.Tecnologistica.com.br/tipo-revista/especial-operadores-logisticos/

Ribeiro, P. C. C., Andrade, A. M., \& Silva, F. A. (2018). A avaliação do Transportation Management System nas operações logísticas de uma empresa de bebidas. Revista GEPROS. Gestão da Produção, Operações e Sistemas, 13(2), 1-20.

Rosenthal, B. (2017). Marketing na era digital. GVExecutivo, 16(1), 16-19. http://dx.doi.org/10.12660/gvexec.v16n1.2017.67451.

Sharma, S., \& Choudhury, A. G. (2014). A qualitative study on evolution of relationships between third-party logistics providers and customers into strategic alliances. Strategic Outsourcing, 7(1), 2-17. http://dx.doi.org/10.1108/SO-08-2013-0015.

Singh Bhatti, R., Kumar, P., \& Kumar, D. (2010). Analytical modeling of third-party service provider selection in lead logistics provider environments. Journal of Modelling in Management, 5(3), 275-286. http://dx.doi.org/10.1108/17465661011092641.

Stevens, G. C., \& Johnson, M. (2016). Integrating the Supply Chain ... 25 years on. International Journal of Physical Distribution \& Logistics Management, 46(1), 19-42. http://dx.doi.org/10.1108/IJPDLM-07-2015-0175.

Thaichon, P., \& Jebarajakirthy, C. (2016). Evaluating specific servisse quality aspects which impact on customers behavioural loyalty in high-tech internet services. Asia Pacific Journal of Marketing and Logistics, 2(1), 141-159. http://dx.doi.org/10.1108/APJML-02-2015-0027.

Vivaldini, M. (2015). Terceirização, quarteirização e primarização logística. Revista GEPROS. Gestão da Produção, Operações e Sistemas, 10(4), 21-38.

Vivaldini, M., \& Pires, S. R. I. (2010). Operadores logísticos: integrando operações em cadeias de suprimento. São Paulo: Editora Atlas.

Vivaldini, M., \& Pires, S. R. I. (2013). Applying a business cell approach to fourth-party logistics freight management in the food service industry. International Journal of Logistics Research and Applications, 16(4), 296-310. http://dx.doi.org/10.1080/13675567.2013.815157.

Win, A. (2008). The value a 4PL provider can contribute to an organization. International Journal of Physical Distribution \& Logistics Management, 38(9), 674-684. http://dx.doi.org/10.1108/09600030810925962. 